удк 339.543

\title{
ЕФЕКТИВНІСТЬ МИТНОГО КОНТРОЛЮ В КОНТЕКСТІ ПРОТИДІЇ ФІСКАЛЬНИМ РИЗИКАМ ТА КОНТРАБАНДНИМ ЯВИЩАМ
}

\section{EFFECTIVENESS OF CUSTOMS CONTROL IN THE CONTEXT OF COUNTERACTING FISCAL RISKS AND SMUGGLING OPERATIONS}

\author{
Крисовата Катерина Вікторівна \\ кандидат економічних наук, \\ Західноукраїнський національний університет \\ ORCID: https://orcid.org/0000-0003-1147-8811 \\ Krysovata Kateryna \\ West Ukrainian National University
}

\begin{abstract}
У статті висвітлюються актуальні аспекти мінімізації митних ризиків та протидії контрабандним явищам на базі ефрективного здійснення митного контролю. Розглянуто теоретико-організаційні та інституційні детермінанти митного контролю в Україні. Обґрунтовано особливості, мотиви та чинники контрабандної діяльності в сучасних умовах розвитку зовнішньоекономічних відносин. Значну увагу приділено моніторингу та аналізу контрабандних поставок в Україну, встановлено що найбільш ризиковими товарними групами виступають машини та електроніка. В результаті оцінки фріскальних ризиків здійснення контрабанди в Україні виявлено, що найбільш суттєвими ризиками виступають фрінансові втрати від ненадходження податку на додану вартість при імпорті товарів. Запропоновано шляхи підвищення митного контролю в контексті протидії фріскальним ризикам та порушенням митних правил з урахуванням зарубіжного досвіду та вимог сучасності.

Ключові слова: митна політика, митний контроль, зовнішньоекономічна діяльність, контрабанда товарів, митний ризик, фріскальні втрати.
\end{abstract}

В статье освещаются актуальные аспекты минимизации таможенных рисков и противодействия контрабандным явлениям на базе эффрективного осуществления таможенного контроля. Рассмотрены теоретикоорганизационные и институциональные детерминанты таможенного контроля в Украине. Обоснованы особенности, мотивы и фракторы контрабандной деятельности в современных условиях развития внешнеэкономических отношений. Значительное внимание уделено мониторингу и анализу контрабандных поставок в Украину, установлено, что наиболее рисковыми товарным группам выступают машины и электроника. В результате оценки фрискальных рисков осуществления контрабанды в Украину выявлено, что наиболее существенными рисками выступают финансовые потери от не поступления налога на добавленную стоимость при импорте товаров. Предложены способы повышения таможенного контроля в контексте противодействия фрискальным рискам и нарушением таможенных правил с учетом зарубежного опыта и требований современности.

Ключевые слова: таможенная политика, таможенный контроль, внешнеэкономическая деятельность, контрабанда товаров, таможенный риск, фрискальные потери.

It is emphasized that in modern conditions the struggle against customs offenses and smuggling is one of the priorities of Ukraine as an independent state in protecting its economic interests. The article highlights the current aspects of minimizing customs risks and combating smuggling on the basis of effective customs control. Theoretical, organizational and institutional determinants of customs control in Ukraine are considered. Peculiarities, motives and factors of smuggling activity in modern conditions of development of foreign economic relations are substantiated. The essence and role of the customs risk management system in the context of increasing the efficiency of customs authorities in Ukraine are determined. Customs offenses and smuggling in particular are detrimental to society as a whole, as well as to specific consumers and foreign economic operators. Considerable attention is paid to monitoring and analysis of smuggled supplies to Ukraine, it is established that the most risk product groups are machinery and electronics. As a result of the assessment of fiscal risks of smuggling in Ukraine, it was found that the most significant risks are financial losses from non-receipt of value added tax on imports of goods. International customs cooperation 
plays a key role in the process of preventing and combating violations of customs rules. Needs to improve the functionality of the customs risk management system in Ukraine based on the implementation of advanced information technologies. The article proposes ways to increase customs control in the context of counteracting fiscal risks and violations of customs rules, taking into account foreign experience and modern requirements. Among which it is important to highlight the following: full-scale introduction of electronic customs declaration; digitization of customs control and clearance mechanisms; simplification and unification of customs control standards; building an effective system of analysis and management of customs risks (based on leading European experience); strengthening the level of liability for violations of customs and tax legislation.

Keywords: customs policy, customs control, foreign economic activity, smuggling of goods, customs risk, fiscal losses.

Постановка проблеми. Націлення України на досягнення європейських стандартів у ссрері митної політики та фріскального регулювання, реалізація стратегії забезпечення економічної безпеки держави спонукають до ретельного моніторингу дестабілізаторів та ризиків у митній справі. Дисрузія контрабандних явищ, з однієї сторони, і порушень митних правил під час митного контролю та офрормлення товарів - 3 іншої, продукують необхідність у побудові ефрективного регуляторного механізму, що забезпечить не лише економічні, але й фрінансові та соціальні ефекти. Сьогодні боротьба з митними правопорушеннями та контрабандними явищами $є$ одним 3 пріоритетних завдань України як незалежної держави у захисті ії економічних інтересів. Економічне зростання держави залежить від швидкого та якісного вирішення цієї проблеми. Не секрет, що це явище набуло нового розвитку: щороку воно має тенденцію поширювати і вдосконалювати діяльність організованих об'єднань, змінювати їх структуру та в сучасній диверсифрікованій соціально-економічній сорері широко розповсюджувати тіньові економічні відносини. У контексті зазначеного, дослідження процесу ефрективного здійснення митного контролю набуває вагомого значення в напрямку протидії митним деліктам, ризикам та контрабандним явищам.

Аналіз останніх досліджень і публікацій. Вагомий внесок у дослідження актуальних питань, пов'язаних із результативністю митного контролю та відпрацюванням митних ризиків зробили низка науковців та орахівців, зокрема: М. Білуха [2], М. Богданов [6], Т. Вишинська [4], І. Гуцул [10], О. Дьяченко [4; 5], С. Литвин [4], Т. Ліпіхіна [1], А. Мазаракі [7], Т. Микитенко [2], Ю. Столєтов [3], Ф. Ткачик [10], В. Угрин [9] та інші. Високо оцінюючи їх зусилля щодо фрормування науково-теоретичної платорорми ефективного фрункціонування митної справи та агломерації шляхів удосконалення контрольної фрункції митних інституцій, слід відмітити наявність багатьох проблемних питань, пов'язаних із загрозами митній безпеці держави. Поряд 3 цим, результати проведених досліджень не повністю забезпечують належного рівня обґрунтування ролі митного контролю у мінімізації фріскальних ризиків та протидії контрабандним потокам.

Формулювання цілей статті. Основною метою роботи $€$ дослідження актуальних аспектів митного контролю та систематизація перспектив його розвитку в контексті мінімізації фріскальних ризиків та протидії контрабандним схемам.

Виклад основного матеріалу дослідження. Сьогодні митний контроль $€$ одним 3 основних видів державного контролю, оскільки постійне зростання зовнішньої торгівлі та міжнародних відносин вимагає посилення контролю на кордоні держави. Система митного регулювання зовнішньоекономічної діяльності (ЗЕД) спрямована на забезпечення дотримання митно-тарифрних і нетарифнних заходів, які державазастосовуєдля захистужиттяіздоров'я населення, навколишнього середовища, а також для захисту своїх економічних інтересів. Водночас, методи митного регулювання можуть самостійно стимулювати розвиток торговельного співробітництва держави і впливати на розвиток її економіки.

Митний контроль в усьому світовому просторі слугує для захисту економічних інтересів держави, а саме:

- в контексті реалізації заходів митнотарифнного регулювання: гарантування сплати ввізних і вивізних мит; дотримання міжурядових і міжнародних угод щодо пресеренційного регулювання; дотримання інших торговельно-політичних заходів;

- в контексті реалізації заходів нетарифрного регулювання: дотримання положень про внутрішні податки; дотримання міжнародних і міжурядових домовленостей про заборони й обмеження [1, с. 66].

Митний контроль $€$ різновидом державного контролю, тому його слід здійснювати на принципах, характерних для всіх різновидів 
державної контрольної діяльності, таких як законність, систематичність, ефективність, гласність, вибірковість, взаємодія.

Суб'єктами митного контролю є система митних органів, посадові особи, які виконують фрункції органів влади у відносинах 3 учасниками зовнішньоекономічної діяльності, пов'язані $з$ переміщенням через митний кордон товарів і послуг, а також транспортних засобів, з іншими особами, які перетинають митний кордон [2, с. 183].

Митний контроль займає провідне місце серед елементів митної справи, оскільки використання саме цього інструменту забезпечує виконання покладених на митниці ДМС України завдань, зокрема ефективність боротьби 3 контрабандою та порушеннями митних правил, наповнення дохідної частини Державного бюджету України, державне регулювання зовнішньоекономічної діяльності, ведення митної статистики тощо.

Система аналізу і управління ризику, на якій базується адміністрування будь-якого бізнес-процесу, є в визначенні пріоритетних і ключових направлень діяльності відповідного розподілу наявних ресурсів. У сучасних умовах згідно зі стандартами та процедурами управління ризиками в митній справі - це основоположний принцип новаторських методів митного контролю, який дозволяє використовувати ресурси митних органів не зменшуючи при цьому ефективності митного контролю, водночас, звільняє більшість суб'єктів зовнішньоекономічної діяльності від надмірного бюрократичного контролю [3].

Прагматизм моніторингу та аналізу ризиків у митній справі свідчить, що це логічний та безперервний процес акумуляції, узагальнення, аналітичної обробки інформаційних масивів, спрямований на прогнозування, виявлення, попередження та припинення митних правопорушень, що забезпечує прийняття ефективних управлінських рішень.

Митні правопорушення та контрабандні явища зокрема, завдають шкоди як суспільству у цілому, так і конкретним громадянамспоживачам та суб'єктам зовнішньоекономічної діяльності, які стали учасниками схем незаконно ввезених товарів. Поряд 3 цим, руйнування внутрішнього виробництва, а як наслідок - скорочення робочих місць та бюджетних соціальних програм, може викликати протести суспільства як у працівників окремої галузі, так й у певних адміністративно-територіальних громадах. Такі явища негативно впливають на соціально-економіч- ний розвиток держави та регіонів, розбалансовують рівень економічної безпеки України.

В українській митній практиці активно використовуються нормативні способи попередження та виявлення митних правопорушень. Зокрема мова йде про митний контроль (постаудит), аналіз митних ризиків, оперативнорозшукову роботу, масово-роз'яснювальну, інорормаційну та соціально-мережеву діяльність митних інституцій в тандемі з правоохоронними органами.

У ході митного контролю посадові особи митного органу вивчають наявні документи на вантаж. Виходячи 3 даних, отриманих у ході документального контролю, вони можуть прийняти рішення й про проведення фрізичного контролю, тобто митного огляду переміщуваних товарів. Важливу роль при проведенні документального контролю відіграє вивчення відомостей про переміщувані товари до того, як з'явиться можливість їх фрізичного контролю $[4$, с. 223]. 3 цією метою використовується такий документ контролю доставки вантажів як попередня митна декларація. За допомогою фрізичного контролю можна перевірити характеристику товарів, що переміщуються через митний кордон, їх якість, кількість, а також встановити чи відповідають вони фрактично задекларованим даним, що вказані у документах, поданих для митного оформлення. У ході митного огляду можуть бути перевірені такі характеристики товарів: відповідність вартості (ії завищення або заниження); відповідність якісних та кількісних характеристик (найменування, якість, кількість, маса); правильність класифрікації за УКТ ЗЕД; відповідність застосування заходів нетарифнного регулювання [5, с. 280].

Незважаючи на те, що частка митних деліктів в загальній структурі злочинності в Україні відносно незначна, проте рівень їх соціальної та економічної небезпеки дуже високий. Це обумовлює необхідність боротьби з цими діяннями, враховуючи усі мотиви (чинники) вчинення, загрози, що виникають та індикатори (критерії) митної злочинності.

Доцільно закцентувати увагу на основних чинниках, які обумовлюють існування контрабандної діяльності:

- низький рівень матеріального забезпечення населення;

- вагома мотиваційна схильність до фрінансових ефектів (ризиків) контрабанди в прикордонних регіонах, де для значної частини мешканців вона перетворилася на основне джерело доходів; 
- висока прибутковість цього виду злочинного бізнесу;

- недосконалість митного та податкового законодавства;

- недостатньо ефективний рівень митного та прикордонного контролю [6, с. 68-69];

- чинники соціально-психологічного характеру;

- невисокий рівень інноватизації технічного забезпечення митного контролю та офрормлення тощо.

Основними предметами контрабанди досить часто виступають промислові та продовольчі товари, транспортні засоби, наркотичні засоби, зброя, боєприпаси, історичні та культурні цінності, валюта, аудіо-, відео-, комп'ютерна та побутова техніка, тютюн, насртопродукти, ювелірні вироби, а останнім часом - лікарські засоби та медичні препарати.

Контрабандні потоки товарів - це дуже поширений спосіб увезення товарів на територію України. Наслідки такої активності впливають на всі сфрери економічного життя країни. Упевнено можна стверджувати, що сучасна контрабанда - одна зі складових організованої злочинності у сфрері економіки.

Тому боротьба 3 контрабандою - першочергове завдання не тільки органів Держмитслужби України, але й держави взагалі, адже потерпає від цього явища насамперед державний бюджет.
Контрабанда - це фрактично звільнення імпортних товарів від будь-яких податків і зборів на території України. Імпортер, отримавши відшкодування ПДВ в середньому на рівні 20\% при вивезенні продукції з країни походження та сплативши близько 5\%, в якості трансакційних витрат на нелегальну доставку продукції в Україну, автоматично набуває непомірної конкурентної переваги над вітчизняним виробником. Таким чином, легальний український бізнес, має суттєві ризики фрінансового характеру, оскільки поступається контрабандному імпорту. Купуючи контрабандний товар і отримуючи короткострокову вигоду, вітчизняний споживач запускає мультиплікатор зниження внутрішнього попиту i, відповідно, згортання виробництва. Як наслідок, підприємства починають скорочувати персонал та зменшувати фронди заробітних плат. Відповідно, реальним платником за існування контрабандних схем в підсумку виступають звичайні громадяни [7, с. 178].

Згідно 3 аналітично-статистичними даними, розраховані обсяги контрабандних поставок в Україну за період 2014-2019 років в середньому складають 10,7 млрд. дол. США на рік, або 8,8\% ВВП. Базуючись на побудованій регресії «обсяги імпорту України - ВВП» та «контрабандні поставки - ВВП» [8], було розраховано прогнозні обсяги контрабандних поставок в Україну у 2020-2022 роках.

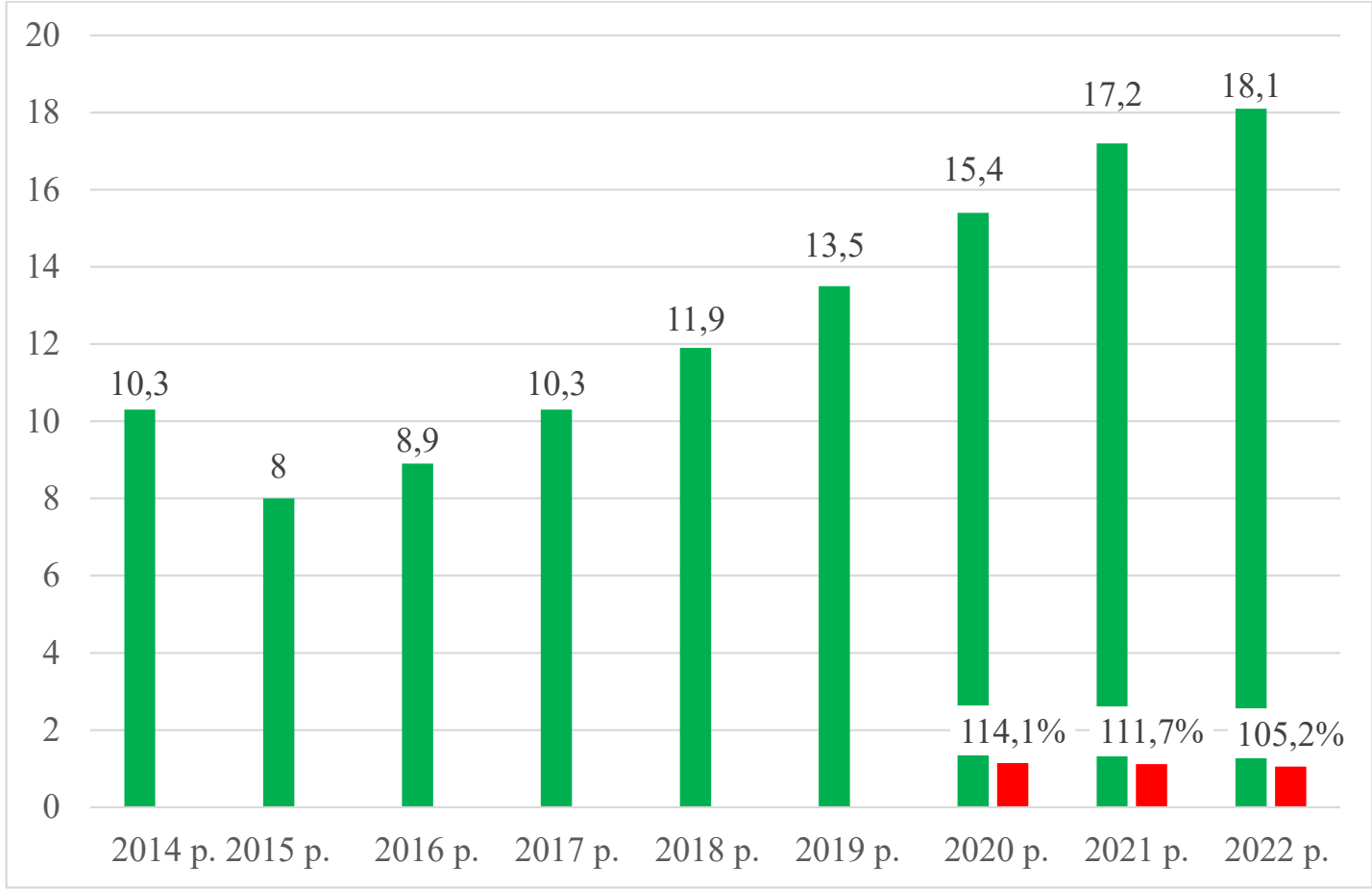

Рис. 1. Обсяги контрабандних поставок в Україну, млрд. дол. США Джерело: складено на основі [8; 9] 
Позитивним моментом можна вважати спадний відсотковий тренд обсягів контрабандних явищ у найближчій дворічній перспективі (див. рис. 1).

Поряд 3 цим, важливо окрему увагу звернути на розподіл контрабандних поставок за основними категоріями товарів. Зокрема, найбільш ризикогенними товарними групами $€$ : машини та електроніка 21,4\%, хімічна продукція 14,3\%, транспорт 10,6\%, текстиль та одяг 9,8\%, аграрний сектор - в середньому по 5\% на кожну підгалузь: продукти тваринного походження продукти рослинництва і продукти харчування.

Цікавим залишається той фракт, що економіка України зазнає вагомих фріскальних ризиків від обсягів контрабандних явищ. Зокрема, в продовження аналізу обсягів контрабандних поставок в Україну в 2014-2022 рр., продемонструємо ймовірні втрати бюджету (див. рис. 2) [8]. Базою для розрахунку поточних ухилень від сплати митних та податкових платежів, які з'являються при імпорті $€$ розраховані обсяги контрабандних поставок в розрізі товарних груп та країн. Це дозволяє врахувати як фрактор дисреренціації митних ставок та акцизних платежів, так і існуючі угоди про безмитну торгівлю з рядом країн, в першу чергу з ЄС.

Найбільш суттєвими ризиками фріскального характеру виступають срінансові втрати від ненадходження податку на додану вартість при імпорті до бюджету. За аналізований період цей показник зріс майже в двічі.

Що стосується протидії контрабанді та порушенням митних правил, зазначимо, що у 2020 році правоохоронними органами було вилучено предметів контрабанди на суму 204 млн. грн. В результаті чого було донараховано 91,6 млн. грн. митних платежів та накладено 31,8 млн. грн. штрафнних санкцій. Що стосується макроекономічного ефректу, то реальна проблема існування контрабандних схем полягає не тільки у фріскальних ризиках, але й спотворенні внутрішнього ринку та розбалансуванні принципів конкуренції від чого першочергово страждає легальний бізнес.

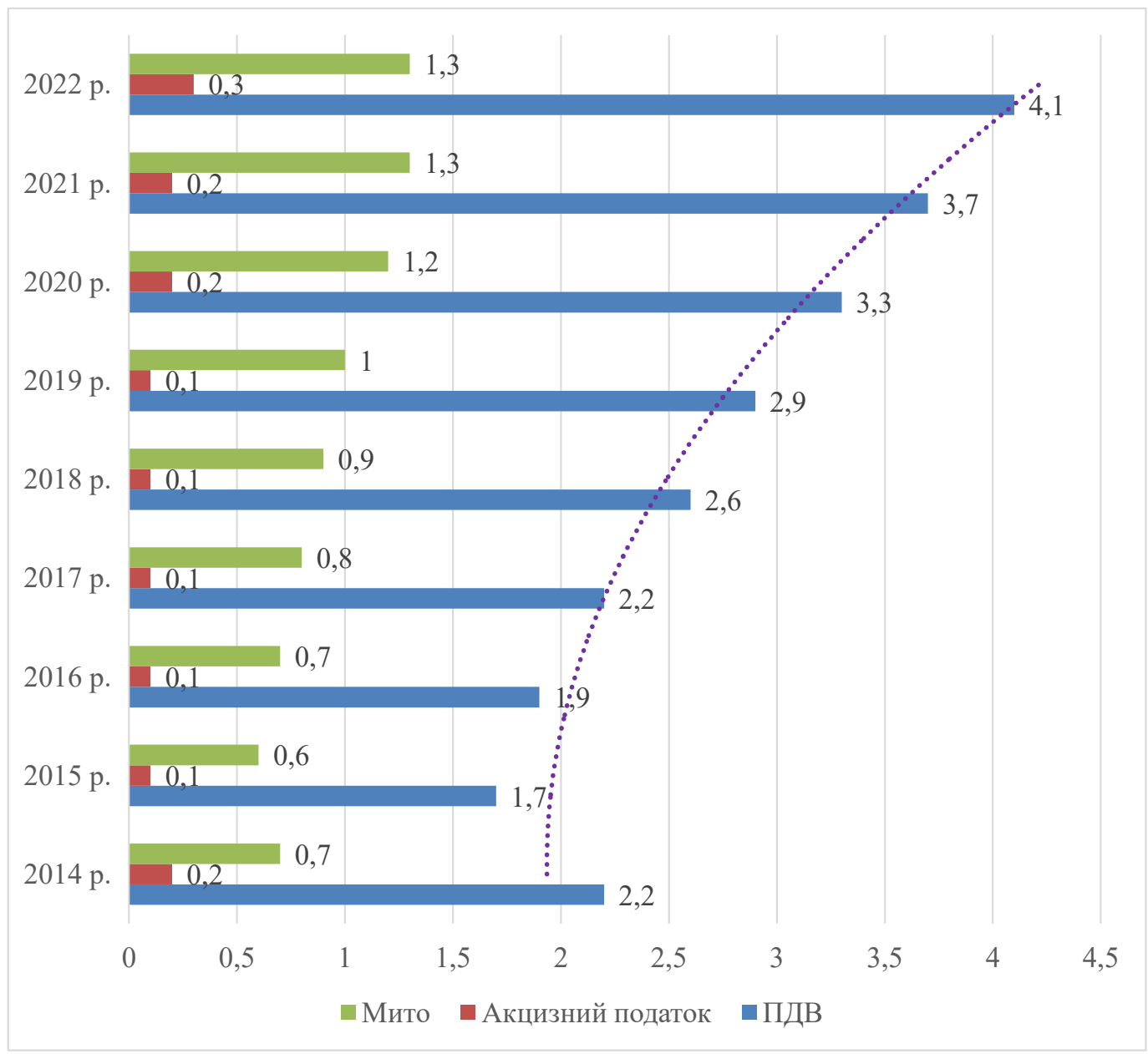

Рис. 2. Фіскальні ризики здійснення контрабандних потоків, млрд. дол. США Джерело: складено на основі [8; 9] 
Відповідно, враховуючи значимість проблеми контрабанди, очевидно, що підхід до ії вирішення має бути комплексним. Тобто, складатися не лише 3 посилення (покращення) контролю на митних постах і кордоні, а й компонуватися за рахунок закриття прогалин на внутрішньому ринку, що дають підстави втілювати різного роду і виду контрабандні схеми [9].

Поряд 3 цим, варто акцентувати, що ключове місце в процесі запобігання та протидії порушенням митних правил займає міжнародне митне співробітництво. Основою міжнародного співробітництва в процесі запобігання та протидії порушенням митних правил $€$ обмін інорормацією щодо діяльності злочинних груп, які діють на території інших держав, діяльності працівників фріскальних та правоохоронних органів під прикриттям, фрактів незаконного переміщення підакцизних товарів, настроїв та дій кінцевих споживачів контрабандних товарів. Результати запобігання та протидії фріскальним ризикам та контрабандним схемам вказують на те, що, незважаючи на застосування комплексу заходів, які здійснюються органами державної влади, зокрема і органами Держмитслужби України, контрабандні потоки є одним із ключових сракторів, які дестабілізують процес розвитку економіки держави, зокрема її стратегічних сфрер, сприяють підвищенню рівня злочинності у сорері економіки [10].

Перспективною $\epsilon$ активізація удосконалення фрункціоналу системи управління митними ризиками в Україні на базі імплементації сучасних інформаційних технологій аналізу та оцінки митних ризиків. На сьогодні для митного контролю товарів, транспортних засобів використовується автоматизована система митного офрормлення, до якої включаються модулі АСАУР, які забезпечують автоматизований аналіз та оцінку ризиків у режимі реального часу при оформленні митних декларацій. В контексті цього, нагальною потребою виступає доопра- цювання програмної платсрорми в напрямку ефективного функціонування автоматизованої системи митного офрормлення, відстеження інсрормації про осіб, які перетинають кордон, зокрема через повітряні пункти пропуску.

Висновки. Модернізація системи митного контролю $є$ базовим напрямом ресрормування митної системи України та має реалізовуватися через: мінімізацію митних і прикордонних формальностей; спрощення митного офрормлення транзиту товарів; створення комсоортних умов для громадян при перетині митного кордону тощо. Базуючись на основних пріоритетах митного контролю в контексті дієвого відпрацювання ризиків та контрабандних схем в Європейському Союзі цікавими для української практики будуть наступні заходи: завершення ресрормування організаційної структури митних органів; розроблення та затвердження порядку виконання митних фрормальностей; інституційне та методичне супроводження процесів управління митними ризиками; вдосконалення процесів управління ризиками та налагодження ефективної співпраці між учасниками зовнішньоекономічної діяльності; імплементація сучасних інформаційних технологій аналізу та оцінки ризиків; інноватизація технічної компоненти митного контролю тощо.

Резюмуючи зазначимо, що перспективними векторами для України в контексті ефективного здійснення митного контролю $€$ повномасштабне запровадження електронного декларування, цифровізація механізмів митного офрормлення, спрощення та уніфрікація нормативів митного контролю, побудова ефективної системи аналізу та управління митними ризиками (на базі адекватного європейського досвіду), посилення рівня відповідальності за порушення норм митно-податкового законодавства як суб'єктами зовнішньоекономічної діяльності, так і самими працівниками (посадовими особами) контролюючих органів, зокрема Держмитслужби України.

\section{СПИСОК ВИКОРИСТАНИХ ДЖЕРЕЛ:}

1. Ліпіхіна Т.Д. Удосконалення системи митного контролю. Аналіз і оцінка ризиків під час здійснення заходів митно-тарифного та нетарифного регулювання ЗЕД. Маркетинг в Україні. 2009. № 1. С. 64-67.

2. Білуха М.Т., Микитенко Т.В. Митний контроль: організація і методологія. Науковий вісник Національного університету ДПС України (економіка, право). 2014. № 1(64). С. 181-187.

3. Столєтов Ю.В. Управління ризиками, як елемент державного регулювання зовнішньоекономічної діяльності. Державне управління: удосконалення та розвиток. 2011. № 10. URL: http://www.dy.nayka.com.ua/ ?ор $=1 \& z=340$

4. Дьяченко О.В., Вишинська Т.Л., Литвин С.М. Митний контроль як один із засобів виявлення правопорушень у сорері митного регулювання зовнішньоекономічної діяльності. Вісник Хмельницького національного університету. 2016. № 2. Том 1. С. 218-227. 
5. Дьяченко О.В. Гармонізація та спрощення національної практики здійснення митних процедур в контексті європейської інтеграції. Вісник Приазовського державного технічного університету. 2015. Вип. 30. С. 276-283.

6. Богданов М.М. Організаційно-правові засади боротьби з контрабандою на сучасному етапі. Митна справа. 2011. № 1. С. 65-70.

7. Митне регулювання зовнішньоекономічної діяльності : підручник / за наук. ред. А.А. Мазаракі. Київ : Київ. нац. торг.-екон. ун-т, 2014. 560 с.

8. Аналіз обсягів контрабанди в Україні. Ukraine economic outlook. URL: http://ua-outlook.com.ua/wp-content/ uploads/2019/07/

9. Угрин В.В. Діджиталізація митного контролю в Україні. Інфрраструктура ринку. 2020. № 47. URL: http://www.market-infr.od.ua/uk/2020

10.Ткачик Ф.П., Гуцул І.А. Митний контроль у забезпеченні економічної безпеки України. Вчені записки Таврійського національного університету імені В.І. Вернадського. Серія : Економіка і управління. 2019. Tом 30(69). № 5. С. 126-130.

\section{REFERENCES:}

1. Lipikhina T.D. (2009) Udoskonalennia systemy mytnoho kontroliu. Analiz i otsinka ryzykiv pid chas zdiisnennia zakhodiv mytno-taryfnoho ta netaryfnoho rehuliuvannia ZED [Improving the customs control system. Analysis and assessment of risks during the implementation of customs and non-tariff measures of foreign economic activity]. Marketynh v Ukraini, no. 1, pp. 64-67.

2. Bilukha M.T., Mykytenko T.V. (2014) Mytnyi kontrol: orhanizatsiia i metodolohiia [Customs control: organization and methodology]. Naukovyi visnyk Natsionalnoho universytetu DPS Ukrainy (ekonomika, pravo), no. 64, pp. $181-187$.

3. Stolietov Yu.V. (2011) Upravlinnia ryzykamy, yak element derzhavnoho rehuliuvannia zovnishnoekonomichnoi diialnosti [Risk management as an element of state regulation of foreign economic activity]. Derzhavne upravlinnia: udoskonalennia ta rozvytok, no. 10. Available at: http://www.dy.nayka.com.ua/?op=1\&z=340

4. Diachenko O.V., Vyshynska T.L., Lytvyn S.M. (2016) Mytnyi kontrol yak odyn iz zasobiv vyiavlennia pravoporushen u sferi mytnoho rehuliuvannia zovnishnoekonomichnoi diialnosti [Customs control as one of the means of detecting offenses in the field of customs regulation of foreign economic activity]. Visnyk Khmelnytskoho natsionalnoho universytetu, no. 2, t. 1, pp. 218-227.

5. Diachenko O.V. (2015) Harmonizatsiia ta sproshchennia natsionalnoi praktyky zdiisnennia mytnykh protsedur v konteksti yevropeiskoi intehratsii [Harmonization and simplification of national practice of customs procedures in the context of European integration]. Visnyk Pryazovskoho derzhavnoho tekhnichnoho universytetu, no. 30, pp. 276-283.

6. Bohdanov M.M. (2011) Orhanizatsiino-pravovi zasady borotby z kontrabandoiu na suchasnomu etapi [Organizational and legal principles of combating smuggling at the present stage]. Mytna sprava, no. 1, pp. 65-70.

7. Mazaraki A.A. (2014) Mytne rehuliuvannia zovnishnoekonomichnoi diialnosti [Customs regulation of foreign economic activity]. Pidruchnyk. Kyiv: Kyiv. nats. torh.-ekon. un-t, 560 p.

8. Analiz obsiahiv kontrabandy v Ukraini [Analysis of the volume of smuggling in Ukraine]. Ukraine economic outlook. Available at: http://ua-outlook.com.ua/wp-content/uploads/2019/07/

9. Uhryn V.V. (2020) Didzhytalizatsiia mytnoho kontroliu v Ukraini [Digitalization of customs control in Ukraine]. Infrastruktura rynku, no. 47. Available at: http://www.market-infr.od.ua/uk/2020

10. Tkachyk F.P., Hutsul I.A. (2019) Mytnyi kontrol u zabezpechenni ekonomichnoi bezpeky Ukrainy [Customs control in ensuring the economic security of Ukraine]. Vcheni zapysky Tavriiskoho natsionalnoho universytetu imeni V.I. Vernadskoho. Seriia: Ekonomika i upravlinnia, no. 5, t. 30(69), pp. 126-130. 